Jurnal Media Analis Kesehatan, Vol. 10, No.1, Juni 2019

http://journal.poltekkes-mks.ac.id/ojs2/index.php/mediaanalis

e-ISSN : 2621-9557

p-ISSN : 2087-1333

\title{
UJI DAYA HAMBAT EKSTRAK DAUN MIANA (Coleus atropurpureus) TERHADAP Escherichia coli
}

\section{Inhibiting Activity of Miana Leave (Coleus atropupureus) on Escherichia coli}

\author{
Anita $^{1}$, Mujahidah Basarang ${ }^{2}$, Rahmawati $^{3}$ \\ 1,2,3 Politeknik Kesehatan Muhammadiyah Makassar \\ 1,2,3 Prodi Teknologi Laboratorium Medik
}

Korespondensi : anitadinar1983@gmail.com/082190344770

\begin{abstract}
Indonesia has many types of plants that can be cultivated because they are useful and of great use to humans in terms of treatment. Plants have a chemical component that can be used as medicine. At this time, many people use natural ingredients which in practice make it a habit to avoid synthetic chemicals and prioritize natural ingredients. One of the plants that contains medicinal compounds is Miana. Miana leaves have antibacterial compounds in the form of flavonoids, tannins, and saponins which function to inhibit bacterial growth. This study aims to determine the activity of Miana leaf extract in inhibiting the growth of Escherichia coli. The sample in this study was Miana leaf extract using five concentrations, namely the concentration of $250 \mathrm{mg} / \mathrm{ml}, 125 \mathrm{mg} / \mathrm{ml}, 62.5 \mathrm{mg} / \mathrm{ml}, 31.25 \mathrm{mg} / \mathrm{ml}$, and $15.62 \mathrm{mg} / \mathrm{ml}$. In this study tetracycline was used as a positive control and aquabides as a negative control with an incubation period of 24 hours at $37^{\circ} \mathrm{C}$ using agar diffusion method. The results of the study at a concentration of $250 \mathrm{mg} / \mathrm{ml}$ had an $18 \mathrm{~mm}$ inhibition zone, a concentration of $125 \mathrm{mg} / \mathrm{ml}$ had a $15 \mathrm{~mm}$ inhibition zone, a concentration of $62.5 \mathrm{mg} / \mathrm{ml}$ had a inhibition zone of $11.3 \mathrm{~mm}$, a concentration of $31.25 \mathrm{mg} / \mathrm{ml}$ had a inhibitory zone 9 $\mathrm{mm}$, and the concentration of $15.62 \mathrm{mg} / \mathrm{ml}$ has a $7 \mathrm{~mm}$ inhibition zone. Based on the results of the study it can be concluded that Miana leaf extract can inhibit the growth of Escherichia coli. This is evidenced by the formation of inhibitory zone diameters around the paper disk and the higher the concentration of miana leaf extract the greater the diameter of the inhibition zone formed.
\end{abstract}

Keywords : Miana leave exctract (Coleus atropupureus), Escherichia coli, Agar difusion method

\section{ABSTRAK}

Indonesia memiliki banyak jenis tanaman yang dapat dibudidayakan karena bermanfaat dan kegunaannya besar bagi manusia dalam hal pengobatan.Tanaman memiliki komponen kimia yang dapat digunakan sebagai obat. Pada saat ini, banyak orang yang menggunakan bahan alam yang dalam pelaksanaannya membiasakan hidup dengan menghindari bahan kimia sintesis dan lebih mengutamakan bahan alami. Salah satu tumbuhan yang mengandung senyawa obat yaitu Miana. Daun miana memiliki senyawa antibakteri berupa flavonoid, tanin, dan saponin yang berfungsi untuk menghambat pertumbuhan bakteri. Penelitian ini bertujuan untuk mengetahui aktivitas 
Jurnal Media Analis Kesehatan, Vol. 10, No.1, Juni 2019

http://journal.poltekkes-mks.ac.id/ojs2/index.php/mediaanalis

e-ISSN : 2621-9557

p-ISSN : 2087-1333

ekstrak daun miana dalam menghambat pertumbuhan Escherichia coli. Sampel dalam penelitian ini adalah ekstrak daun miana dengan menggunakan lima konsentrasi yaitu konsentrasi $250 \mathrm{mg} / \mathrm{ml}, 125 \mathrm{mg} / \mathrm{ml}, 62,5 \mathrm{mg} / \mathrm{ml}, 31,25 \mathrm{mg} / \mathrm{ml}$, dan 15,62 mg/ml. Pada penelitian ini digunakan tetrasiklin sebagai kontrol positif dan akuabides sebagai kontrol negatif dengan masa inkubasi selama 24 jam pada suhu $37^{\circ} \mathrm{C}$ menggunakan metode difusi agar. Hasil penelitian pada konsentrasi $250 \mathrm{mg} / \mathrm{ml}$ memiliki zona hambat $18 \mathrm{~mm}$, konsentrasi $125 \mathrm{mg} / \mathrm{ml}$ memiliki zona hambat $15 \mathrm{~mm}$, konsentrasi $62,5 \mathrm{mg} / \mathrm{ml}$ memiliki zona hambat $11,3 \mathrm{~mm}$, konsentrasi $31,25 \mathrm{mg} / \mathrm{ml}$ memiliki zona hambat $9 \mathrm{~mm}$, a konsentrasi 15,62 $\mathrm{mg} / \mathrm{ml}$ memiliki zona hambat $7 \mathrm{~mm}$. Berdasarkan hasil penelitian dapat disimpulkan bahwa ekstrak daun miana mampu menghambat pertumbuhan Escherichia coli. Hal ini terbukti dengan terbentuknya diameter zona hambat disekitar paper disk dan Semakin tinggi konsentrasi ekstrak daun miana maka semakin besar diameter zona hambat yang terbentuk.

Kata Kunci : Ekstrak Daun Miana (Coleus atropurpureus), Escherichia coli, Metode Difusi Agar.

\section{PENDAHULUAN}

Indonesia memiliki banyak jenis tanaman yang dapat dibudidayakan karena bermanfaat dan kegunaannya besar bagi manusia dalam hal pengobatan. Tanaman yang memiliki komponen kimia yang dapat digunakan sebagai obat. Pada saat ini, banyak orang yang menggunakan bahan alam yang dalam pelaksanaannya membiasakan hidup dengan menghindari bahan kimia sintesis dan lebih mengutamakan bahan alami. Salah satu tumbuhan yang mengandung senyawa obat yaitu Miana (Ridwan, 2010).

Telah diketahui beberapa studi tentang senyawa aktif antimikrobial daun miana (Coleus atropurpereus yaitu berupa flavonoid, saponin, steroid , tanin, minyak atsiri, eugenol, senyawa polifenol, alkaloid, etil salisilat, kalsium oksalat, senyawa rosmarinic acid (RA) (Ridwan, 2010).

Escherichia coli adalah salah satu jenis bakteri yang secara normal hidup dalam saluran pencernaan dan umum ditemukan didalam usus manusia (Marianti, 2017).

Penelitian yang dilakukan oleh Deby A. Mpila, Fatimawali, Weny L
Wiyono pada tahun 2012 dengan judul Uji Efektivitas Anti Bakteri Ekstrak Etanol Daun Mayana (Coleus atropurpureus L Benth) Terhadap Staphylococcus aureus, Escherichia coli dan Pseudomonas aeruginosa Secara In-Vitro menyatakan bahwa konsentrasi ekstrak daun miana 20\%, $40 \%$, dan $80 \%$ merupakan konsentrasi efektif untuk menghambat bakteri Staphylococcus aureus. Konsentrasi ekstrak 10\%, 20\%, 40\% dan 80\% merupakan konsentrasi efektif untuk menghambat bakteri Escherichia coli. Sedangkan konsentrasi ekstrak $40 \%$ dan $80 \%$ merupakan konsentrasi efektif untuk menghambat bakteri Pseudomonas aeruginosa (Karmila, 2017).

Dari beberapa penelitian ini terbukti bahwa ekstrak daun miana memiliki sifat anti bakteri, karena ekstrak daun miana mengandung flavonoid, saponin, dan tanin.

Dari beberapa uraian diatas penulis tertarik untuk melakukan penelitian tentang uji daya hambat bakteri Escherichia coli dengan menggunakan ekstrak daun miana dengan tujuan untuk mengetahui kemampuan ekstrak daun miana dalam 
menghambat pertumbuhan bakteri Escherichia coli.

\section{METODE}

Jenis penelitian yang digunakan adalah eksperimen menggunakan eksperimen untuk melihat mampu atau tidaknya daun miana dalam menghambat pertumbuhan Escherichia coli. Penelitian dilaksanakan di Laboratorium Bakteriologi Politeknik Kesehatan Muhammadiyah Makassar pada bulan April 2019.

Sampel yang digunakan dalam penelitian ini adalah ekstrak daun miana (Coleus atropurpereus). Dengan Teknik pengambilan sampel adalah Random Sampling.

Alat yang digunakan dalam penelitian yaitu autoclave, gelas kimia, gelas ukur, inkubator, lampu spiritus, cawan petri besar dan kecil, timbangan, api bunsen, rotavapor, ose, paper disk, pinset, rak tabung, tabung reaksi, swab steril, oven, pipet steril. Sedangkan Bahan yang digunakan yaitu ekstrak daun miana, biakan murni, Media Mueller Hinton Agar (MHA), Nurien Agar (NA), kapas, $\mathrm{NaCl}$ Fisiologis, DMSO, Akuades, Akuabides, $\mathrm{BaCl}_{2}$ $1 \%, \mathrm{H}_{2} \mathrm{SO}_{4} 1 \%$, Kotton bad, Etanol 96\%, Tetrasiklin.

Prosedur Kerja

1) Sterilisasi Alat

Seluruh peralatan yang digunakan selama penelitian harus dibersihkan dengan cara dicuci dan dikeringkan lalu dibungkus dengan kertas aluminium foil. Kemudian dilakukan sterilisasi didalam autoclave selama 15 menit pada suhu $121^{\circ} \mathrm{C}$ ( Nuraini, 2018).

2) Persiapan sampel dan pembuatan ekstrak Etanol

Pengambilan sampel daun miana (Coleus atropurpureus) dilakukan dengan cara daun miana diambil di pagi hari. Lalu dikeringkan selama 5 hari, setelah itu dihancurkan tapi tidak sampai halus.Direndam dengan etanol $96 \%$ selama 7 hari.Disaring, lalu memisahkan supernatan dan filtratnya.Filtrat dibuang, supernatan di rotavavor. Hasil akhir ekstrak daun miana setelah dirotavapor sebanyak 5,34 gr.

3) Pembuatan Larutan Kontrol Positif Kontrol positif yang digunakan adalah tetrasiklin. Dibuat dengan cara tetrasiklin $500 \mathrm{mg}$ ditambahkan $10 \mathrm{~mL}$ aquadest.

4) Persiapan Bakteri Uji

Satu mata ose bakteri Escherichia coli murni digoreskan pada media Nutrien Agar, lalu diinkubasi selama 24 jam pada suhu $37^{\circ} \mathrm{C}$.

5) Pembuatan Larutan Mac Farland $0,5 \%$

Larutan baku Mac Farland terdiri atas 2 komponen, yaitu larutan $\mathrm{BaCl}_{2}$ dan $\mathrm{H}_{2} \mathrm{SO}_{4}{ }_{1} \%$. Larutan $\mathrm{BaCl}_{2} 1 \%$ sebanyak $0,05 \mathrm{ml}$ dicampur dengan larutan $\mathrm{H}_{2} \mathrm{SO}_{4} 1 \%$ sebanyak 9,95 ml dalam labu takar hingga homogen. Suspensi ini digunakan sebagai larutan standar pembanding kekeruhan suspensi.

6) Pembuatan Suspensi Bakteri

Biakan Escherichia coli yang sudah diremajakan diambil seujung mata ose dan disuspensi pada $\mathrm{NaCl}$ fisiologis kemudian dibuat kekeruannya dibandingkan dengan standar Mac Farland 0,5\%.

7) Pembuatan Media Mueller Hinton Agar (MHA)

Bahan yang akan digunakan ditimbang sebanyak 4,56 gr dibuat dalam $120 \mathrm{ml}$ aquades, dipanaskan pada hot plate agar semua bahan larut sempurna. Larutan kemudian dipipet $20 \mathrm{ml}$, dan dimasukkan 
kedalam cawan petri dan biarkan hingga membeku.

8) Pengujian Uji Daya Hambat

Diambil hasil suspensi bakteri dengan menggunakan swab steril lalu diusapkan merata pada seluruh permukaan media MHA. Kemudian ditempelkan masingmasing paper disk yang sudah direndam pada ekstrak daun miana sesuai konsentrasi selama \pm 30 menit dan kontrol positif (tetracycline) serta kontrol negatif (aquabidest). Paper disk diletakkan dipermukaan media MHA menggunakan pinset steril dan diinkubasi selama 24 jam pada suhu $37^{\circ} \mathrm{C}$.

Bahan uji dikategorikan positif apabila uji hasil laboratorium pada ekstrak daun miana dapat menghambat pertumbuhan Escherichia coli yang ditandai dengan terbentuknya zona hambat yang terbentuk disekitar paper disk.

9) Interpretasi Hasil
Penilaian diameter zona hambat antibiotik tetrasiklin :

Resisten : $<11 \mathrm{~mm}$

Intermediate : $12-14 \mathrm{~mm}$

Sensitif : >15 mm (CLSI, 2013).

Analisis Data

Data dari penelitian ini diolah secara deskriptif dan disajikan dalam bentuk tabel.

\section{HASIL}

Berdasarkan penelitian yang telah dilakukan pada tanggal $8-13$ April 2019 di Laboratorium Bakteriologi Prodi D-III Teknologi Laboratorium Medis Politeknik Kesehatan Muhammadiyah Makassar yaitu uji daya hambat ekstrak daun miana (Coleus atropurpureus) terhadap Escherichia coli dengan menggunakan metode difusi agar dalam cawan petri berisi media MHA (Mueller Hinton Agar) yang telah diinkubasi selama 24 jam pada suhu $37^{\circ} \mathrm{C}$ diperoleh hasil sebagai berikut :

Tabel 1. Hasil uji daya hambat ekstrak daun miana (Coleu atropurpureus) terhadap Escherichia coli.

\begin{tabular}{lcccc}
$\begin{array}{l}\text { Konsentarsi } \\
\text { Estrak } \\
(\mathbf{m g} / \mathbf{m l})\end{array}$ & $\begin{array}{c}\text { Replikasi } \\
\text { I }\end{array}$ & $\begin{array}{c}\text { Replikasi } \\
\text { II }\end{array}$ & $\begin{array}{c}\text { Replikasi } \\
\text { III }\end{array}$ & Total \\
\hline 250 & 16 & 18,5 & 19 & 18 \\
125 & 15 & 15 & 15 & 15 \\
62,5 & 12 & 10 & 12 & 11,3 \\
$\quad 31,25$ & 9 & 8 & 10 & 9 \\
$\quad 15,62$ & 7 & 7 & 7 & 7 \\
$\begin{array}{l}\text { Kontrol } \\
\text { negatif }\end{array}$ & 0 & 0 & 0 & 0 \\
(akuades) & & & & \\
Kontrol & 20 & 24 & 24 & 23 \\
poisitif & & & & \\
(tetrasiklin) & & & & \\
\hline
\end{tabular}

Berdasarkan hasil penelitian uji daya hambat ekstrak daun miana (Coleus atropurpureus) terhadap Escherichia coli diperoleh hasil dengan konsentrasi $250 \mathrm{mg} / \mathrm{ml}$ mendapatkan zona hambat $18 \mathrm{~mm}, 125 \mathrm{mg} / \mathrm{ml}$ mendapatkan zona hambat $15 \mathrm{~mm}, 62,5$ $\mathrm{mg} / \mathrm{ml}$ mendapatkan zona hambat 11,3 $\mathrm{mm}, 31,25 \mathrm{mg} / \mathrm{ml}$ mendapatkan zona 
hambat $9 \mathrm{~mm}$, dan 15,62 $\mathrm{mg} / \mathrm{mlmendapatkan}$ zona hambat $7 \mathrm{~mm}$. Sedangkan pada kontrol Positif mendapatkan hasil $23 \mathrm{~mm}$ dan kontrol negatif mendapatkan hasil $0 \mathrm{~mm}$ (tidak terbentuk zona hambat).

\section{PEMBAHASAN}

Penelitian tentang uji daya hambat ekstrak daun miana (Coleus atropurpureus) terhadap Escherichia colidilakukan secara eksperimen laboratorik yang dilakukan di Laboratorium Bakteriologi Politeknik Kesehatan Muhammadiyah Makassar. Sampel pada penelitian ini adalah ekstrak daun miana dengan metode maserasi.

Metode maserasi adalah salah satu cara untuk memisahkan senyawa metabolit sekunder dari sampel tanaman dengan perendaman menggunakan pelarut organik tanpa pemanasan (Hidayati, 2017). Daun miana dikering anginkan selama 5 hari yang bertujuan untuk menghilangkan komponen air didalam daun miana. Daun miana direndam dengan etanol $96 \%$ yang berfungsi sebagai pelarut yang akan melarutkan zat aktif yang terkandung dalam sampel, dan dibuat menjadi ekstrak dengan menggunakan Rotavapor.

Kontrol positif yang digunakan dalam penelitian ini adalah tetracycline $500 \mathrm{mg}$, hal ini didasarkan bahwa antibiotik ini diketahui dapat menghambat pertumbuhan bakteri dan menghambat sintesis protein dan ribosom (Wasitaningrum, 2009). Kontrol positif juga digunakan untuk menguji apakah kultur bakteri yang digunakan dalam penelitian masih layak untuk diuji atau tidak. Sedangkan kontrol negatif dalam penelitian ini adalah aquabides steril yang bertujuan untuk melihat apakah pengerjaan yang dilakukan dengan benar atau tidak.
Pelarut DMSO berfungsi untuk melarutkan ekstrak daun miana, karena DMSO bersifat polar.

Berdasarkan hasil penelitian ekstrak daun miana mempunyai daya hambat terhadap pertumbuhan Escherichia coli. Hal ini terbukti dengan terbentuknya diameter zona hambat disekitar paper disk. Hasil penelitian menunjukkan bahwa pada ekstrak daun miana dengan konsentrasi $250 \mathrm{mg} / \mathrm{ml}$ mendapatkan zona hambat $18 \mathrm{~mm}$, konsentrasi $125 \mathrm{mg} / \mathrm{ml}$ mendapatkan zona hambat $15 \mathrm{~mm}$, konsentrasi $62,5 \mathrm{mg} / \mathrm{ml}$ mendapatkan zona hambat $11,3 \mathrm{~mm}$, konsentrasi $31,25 \mathrm{mg} / \mathrm{ml}$ mendapatkan zona hambat $9 \mathrm{~mm}$, konsentrasi $15,62 \mathrm{mg} / \mathrm{ml}$ mendapatkan zona hambat $7 \mathrm{~mm}$. Dari hasi penelitian menunjukkan bahwa pada ekstrak daun miana dengan konsentrasi tinggi mendapatkan hasil zona hambat yang lebih luas dibanding dengan konsentrasi rendah yang artinya konsentrasi ekstrak daun miana yang paling efektif dalam menghambat pertumbuhan Escherichia coli adalah konsentrasi $250 \mathrm{mg} / \mathrm{ml}$.

Berdasarkan data diatas jika dibandingkan dengan kontrol positif menunjukkan bahwa konsentrasi ekstrak daun miana $250 \mathrm{mg} / \mathrm{ml}$ dengan zona hambat $18 \mathrm{~mm}$ menunjukkan sensitif, konsentrasi $125 \mathrm{mg} / \mathrm{ml}$ dengan zona hambat $15 \mathrm{~mm}$ menunjukkan sensitif, konsentrasi $62,5 \mathrm{mg} / \mathrm{ml}$ dengan zona hambat $11,3 \mathrm{~mm}$ menunjukkan intermedian, konsentrasi $31,25 \mathrm{mg} / \mathrm{ml}$ dengan zona hambat $9 \mathrm{~mm}$ menunjukkan resisten, konsentrasi $15,62 \mathrm{mg} / \mathrm{ml}$ dengan konsentrasi $7 \mathrm{~mm}$ menunjukkan resisten.Karena interpretasi hasilnya yaitu resisten $<11$ $\mathrm{mm}$, intermedian $12-14 \mathrm{~mm}$, dan Sensitif $>15 \mathrm{~mm}$.

Kemampuan ekstrak daun miana menghambat pertumbuhan Escherichia coli karena mengandung 
zat aktif yang berperan sebagai antibakteri, diantaranya saponin, tanin, dan flavonoid yang dapat melisiskan dinding sel bakteri.

Saponin dapat menyebabkan terjadinya penurunan tegangan permukaan dinding sel bakteri yang dapat menyebabkan kebocoran sel sehingga pertumbuhan sel bakteri terhambat. Senyawa tanin berperan sebagai antibakteri dengan menghambat pembentukan polipeptida dinding sel bakteri sehingga lapisan dinding sel tidak terbentuk secara utuh dan dapat menyebabkan lisisnya dinding sel bakteri. Flavonoid juga dapat menghambat proses replikasi DNA dan menghambat fungsi membran sel bakteri sehingga mengakibatkan mengakibatkan kerusakan pada sel bakteri dan akhirnya kematian sel bakteri (Maufti N, 2017).

Escherichia coli merupakan bakteri gram negatif. Bakteri ini berbentuk batang, Gram-negatif, fakultatif aerob, flora normal, tumbuh baik pada media sederhana.

\section{KESIMPULAN}

Berdasarkan hasil penelitian dapat disimpulkan bahwa ekstrak daun miana (Coleus atropurpureus) dapat menghambat pertumbuhan Escherichia coli dengan konsentrasi $250 \mathrm{mg} / \mathrm{ml}$ mendapatkan zona hambat $18 \mathrm{~mm}, 125$ $\mathrm{mg} / \mathrm{ml}$ mendapatkan zona hambat 15 $\mathrm{mm}, 62,5 \mathrm{mg} / \mathrm{ml}$ mendapatkan zona hambat $11,3 \mathrm{~mm}, \quad 31,25 \mathrm{mg} / \mathrm{ml}$ mendapatkan zona hambat $9 \mathrm{~mm}$, dan $15,62 \mathrm{mg} / \mathrm{ml}$ mendapatkan zona hambat $7 \mathrm{~mm}$.

\section{SARAN}

Disarankan untuk penelitian selanjutnya menguji zat aktif yang terkandung dalam daun miana yang menghambat pertumbuhan bakteri lainnya.

\section{UCAPAN TERIMA KASIH}

Peneliti mengucapkan banyak terima kasih kepada Direktur Politeknik Kesehatan Muhammadiyah Makassar yang telah memberikan bantuan dana hibah penelitian internal, dan kepada Kaprodi Teknologi Laboratorium Medik dan Ka.Unit Laboratorium, Teknologi Laboratorium Medik yang telah memberikan izin yang mendukung kelancaran penelitian kami.

\section{DAFTAR PUSTAKA}

CLSI. 2013. Disc diffusion suoolemental tables (online), (http://www.oxoid.com/pdf/uk/2 013-CLSIFDA-tableupdate.pdf\&ved $=2$ ahUKEwi48 YaB5pPiAhXyheYKHYOBAR kQFjAAegQIAhAB\&usg=AOv Vaw1dSbQoh7CbSONVO1nlvx $\underline{\mathrm{vD}}$, diunduh 2013).

Ditjen POM. 2000. Parameter Standar Umum Ekstrak Tumbuhan Obat. Cetakan Pertama. Jakarta : DapartemenKesehatan RI.

Hartono T. 2017. Saponin (online), (http://www.farmasi.asia/saponi n/,diunduh 31 Maret 2017).

Hendra. 2017. Dahsyat! Inilah 15 Manfaat Penting Daun Miana bagiKesehatan (online), (http://dangdutan.me/watch/V3E vwv-qVJ4/, diunduh 6 Juni 2017).

Hidayati AS dan Harjono. 2017. Uji Aktivitas Antibakteri Krim Ekstrak Daun Babadotan (Ageratum conyzoides. L) dalam Pelarut Etanol (online), (http://journal.unnes.ac.id/nju/in dex.php/JM, diunduh 1 April 2017).

Irianto K. 2014. Bakteriologi, Mikologi, dan Virologi Panduan Medis danKlinis. ALFABETA, cv: Bandung. 
Khairunizzahra Badzlina. 2019. Pengertian dan Kegunaan Tanin (online),(http://id.scribd.com/do cument/363078524/Pengertian-

Dan-Kegunaan-Tanin, diunduh 2019).

Karmila. 2017. Uji Daya Hambat Ekstrak Gel Lidah Buaya (Aloe Vera)Dalam Menghambat Pertumbuhan Bakteri Escherichia coli. KaryaTulis Ilmiah (KTI) : Akademi Analis Kesehatan MuhammadiyahMakassar.

Marianti. 2017. Gejala, Penyebab dan Mengobati Escherichia coli(online),

(http://www.alodokter.com/ecoli, diunduh 27 Juli 2017).

Mufti Nastasha, Bahar Elizabeth, Arisanti Dessy. 2017. Uji Daya Hambat Daun Sawo terhadap Bakteri Escherichia coli secara In Vitro (online), (http://jurnal.fk.unand.ac.id/inde x.php/jka/article/view/693, diunduh 2017).

Rahmatullah Ahmad Marzuki. 2013. Studi Karakterisasi BakteriEscherichia coli (online), (http://www.academia.edu/4139 114/e.coli,diunduh 27 Mei 2013).

Wasitaningrum Ika Dyah Ayu. 2009. Uji Resistensi Bakteri Staphylococcus aureus dan Escherichia coli Dari Isolasi Susu Segar Terhadap Beberapa Antibiotik (online), (http://eprints.ums.ac.id/7689/, diunduh 2009).

YRidwan. 2010. Efektivitas Anticestoda Ekstrak Daun Miana (Coleusblumei Bent) terhadap Cacing Hymenolepis microstoma padaMencit (online),(http://www.researchgat e.net/publication/50434346, diunduh April 2010).

Yolanda Natharina. 2014. Escherichia coli

(online),(http://www.kerjanya.ne t/faq/6588-escherichia-coli.html, diunduh 24 Maret 2014).

Yuwono Sudarminto S. 2015. Daun Miana (Coleus benth) (online),http://darsatop.lecture.u b.ac.id/2015/08/daun-mianacoleus-benth/, diunduh 27 Agustus 2015). 